\title{
Making ICTs relevant to rural farmers in Uganda: A Case of Kamuli District
}

\author{
Winny Nekesa Akullo \\ winny.nekesa@yahoo.com \\ Public Procurement and Disposal of Public
Assets Authority, Kampala, Uganda. \\ Onan Mulumba \\ omulumba@mulib.mak.ac.ug \\ Agricultural and Environmental Sciences, \\ Kampala, Uganda.
}

\begin{abstract}
ICTs stands for information and Communication Technologies, it has been broadly defined by the Uganda Communication Commission as technologies that provide an enabling environment for physical infrastructure and services development of application for generation, transmission processing, storing and disseminating information in all forms, including voice, text, data, graphics and video. ICTs are not effectively communicated to farmers especially in rural areas although access to modern information technology is largely available. This paper will examine the relevance of ICTs to the rural farmers in Uganda. The objectives of the study are to investigate agricultural information needs of rural farmers in Kamuli district; to identify the ICT facilities used for dissemination agricultural information to rural farmers. The sample size was 62 respondents. Random sampling was used in identifying the respondents. Questionnaires was used to solicit responses from the respondents. Data was analysed using Ms. Excel and presented in tables. From the study, the majority of the respondents were males and the radio was the main ICT equipment used for accessing agricultural information. One of the major challenges to access of the ICTs is inadequate funding and training. It was therefore, recommended the need for government intervention to provide subsides and also establish training sectors for the rural farmers to access the agricultural information on other ICTs facilities.
\end{abstract}

KEYWORDS: ICTS. Rural Farmers. Dissemination. 


\section{INTRODUCTION}

In most developing countries Agriculture is the main economic activity accounting for large shares of employment and output. In Uganda over 80 percent of the households and 85 percent of the people live in rural areas and most of these largely depend on Agriculture as their main source of income (Gollin\& Rogerson, 2010). Information and Communications Technologies (ICTs), are broadly defined as tools that enable,electronically, the creation, storage, management and dissemination of information(Baryamureeba, 2004). The main focus in this paper is on the agricultural information needs and the use of ICTs to enhance access to information by the rural farmers in Kamuli District, one of the districts found in Eastern Uganda. The paper specifically dwells on the relevance of the ICTs in enhancing Agriculture in the area. The communication channelsmay range from: mobile network devices such as phones and tablets, radio, television, telephone, fax, computers and the Internet. Newspapers are also currently a major information medium accessible through the internet.

Information and communication have always mattered in agriculture, ever since people started growing crops, raising animals, and fishing. Farmers have always sought information from each other. For example farmers could seek information to answer questions relating to; the most effective planting strategy on steep slopes, sources ofimproved seeds or feeds, how to acquire a land title,current market prices of agricultural produce, and procedures to participate in the government credit programs, among other issues. Farmers do not usuallyget appropriate answers to questions arising from their concerns, even though the same issues arise season after season and year after year (The International Bank for Reconstruction and Development \& The World Bank, 2011).

According to Qiang et al. (2012) mobile communications technology has rapidly become the world's most common way of transmitting voice, data, and services in the developing world. Given this dramatic change, mobile applications (M-apps) in general and mobile applications for Agricultural and Rural Development (m-ARD apps) in particular hold significant potential for advancing development. They could provide the most affordable ways for millions of people to access information, markets, finance, and governance systems previously unavailable to them.

Appropriate dissemination of Agricultural information requires suitable Knowledge Management practices and skills. The main focus is put on knowledge generation, processing of the acquired information resources and proper dissemination to the target population (RAO et al., 2015).

\section{BRIEF INTRODUCTION}

Uganda is a landlocked country with estimated 34.7 million people. Over $80 \%$ of the population is engaged in Agriculture sector mainly for subsistence livelihood and the country heavily depends on agriculture as its major economic activity. It hasbeenestimatedthat $90 \%$ of the Uganda nwomen. 


\section{PROBLEM STATEMENT}

In Agricultural projects and farm records management, traditionally, pen and paper have been used to collect data in the field and for monitoring and evaluation of projects in rural areas. However, this approach is time consuming and susceptible to human error that may affect productivity and accuracy. Information and communication technologies are now being used widely with remarkable positive results to perform these tasks in agricultural development projects (CESPEDES, 2013). Although access to modern information technology is largely available, the promotion of the use of ICTs in Agricultural Information Services is tailored around the many advantages and opportunities that accompany them, including; ease of use, provider sustainability, timely delivery of updated information, and a wider reach out.

However, the practice of Using ICTs has not widely cascaded to most rural areas in Uganda. It is therefore necessary to study and understand the agricultural information needs and information seeking behaviors related to the use of ICTs, by the farmers in the area of study, Kamuli District.

\section{OBJECTIVES OF THE STUDY}

The objectives of this study were to:

- Investigate agricultural information needs of rural farmers in Kamuli district.

- Identify the ICT facilities used for dissemination agricultural information to rural farmers.

- Identify the sources of agricultural information

- Identify challenges farmers face in accessing ICTs for agricultural information.

- Propose measures on how ICTs can be used to improve access to agricultural information by the rural farmers.

\section{JUSTIFICATION OF THE STUDY}

For modernization of Agriculture in Uganda; this study will draw attention of stakeholders in the agriculture sector to support and promote the use of ICTs as an effective tool in disseminating agricultural information to the rural farmers.

\section{LITERATURE REVIEW}

Uganda has the requisite policy framework for modernizing agriculture and eradicating poverty in place and the onus is on scientists to provide environmentally sound technology options to ensure policy implementation In this regard, scientists will require support and innovative dissemination strategies, which include among others information dissemination and financing mechanisms to ensure that the technologies are adopted (TURYAREEBA, 2001). A key feature of the of the Ugandan economy is the large fraction of individuals 
engaged in farming and at the same time productivity is low relative to the nonagricultural sector (GOLLIN; ROGERSON, 2010). In the survey about ICT uses for inclusive agricultural value chains by (FAO, 2013) it was predicted that most developing countries would in the coming years be in position to access agricultural information services through the internet using their mobile phone applications. This practice is observed in a number of sectors in the country and would therefore be very useful in enhancing agricultural production in the rural communities.

\section{INFORMATION NEEDS OF RURAL FARMERS:}

No one can categorically claim to know all the information needs of farmers especially in an information dependent sector like agriculture where there are new and rather complex problems facing farmers every day (OZOWA, 1995). Information needs of the rural communities are issues to deal with food production, food marketing and food utilization (KOBUSINGE, 2009). Ozowa(1995) further connotes that the information needs may be grouped into five headings: agricultural inputs; extension education; agricultural technology; agricultural credit; and marketing. In a study carried out by CTA (2005) to assess the agricultural information needs in African, Caribbean \& Pacific (ACP) states it was established that most farmers required information in journals and bulletins, in food security, rural livelihoods, participatory methods and rural livelihoods.

\section{ICT REQUIREMENTS BY RURAL FARMERS}

Mobile phones, GPS systems, barcode scanners, RFID readers and smart card readers are all examples of technologies that can be used to capture, read and store data(ZYL et al., 2014). However, further components, such as the internet, communication networks and regulatory systems (to provide data security and standard systems for codes) are essential to complement the input and output devices. In a study about an ICT Framework to Enhance Food Security in Rural Communities of Uganda. Kobusinge(2009) established five most effective ways through which ICT can enhance agricultural production and these include; radios, mobile phones, internet, print outs and workshops.

\section{SOURCES OF INFORMATION}

A study on the sources of agricultural information by Jones (1990) reveals that books, journals, conference proceedings, maps, theses, reports, remote sensing imagery, patents, and other types of information emanating from tens of thousands of sources are a testament to the richness of the field which must somehow be managed. However, with the evolution of ICT, recent studies reveal that radio is more effective and preferential in dissemination of agricultural information (ISAYA, 2015; MUSA, 2013). 


\section{CHALLENGES FACED IN ACCESSING AGRICULTURAL INFORMATION}

According to a study conducted by Obidike (2011) to determine the rural farmers problems in accessing agricultural information in Nigeria, it was found out that the most prominent impediments to accessing agricultural information stem from inadequate financial power of farmers, few number of extension workers, higher levels of illiteracy, lack of basic infrastructure, such as telephone and electricity, and poor radio and television reception signals. The main challenges associated with access to agricultural information through Television include; few opportunities to watch television, short air times, and the fact that agriculture programs are not the farmers' main preference in terms of what to watch (RAMLI et al., 2013).

\section{BENEFITS OF ICTS}

The benefits of ICT in agricultural production include; timely and updated information on agriculture related issues such as new varieties release, emergence of new threats such as diseases, weather forecast, pricing control, warning alerts (DAS, 2013) as well as applications (apps) to help buyers manage transactions with the thousands of small-scale farmers who supply to them mobile banking and apps that facilitate quick payments, initiatives to expand the reach of farm extension services through phone, radio, video and sometimes all three, Short Message Services (SMS) or text messaging campaigns for enabling environment advocacy (HALL, 2011).

\section{PROPOSAL ON IMPROVING ACCESS OF AGRICULTURAL INFORMATION THROUGH USE OF ICTS}

Whereas technical factors such as packaging of information, skills of staff and technicians of ICT centers, and methods of dissemination, Musa (2013) suggests that, ensuring that dissemination methods adopt accessible technologies, which include radio and TV can address technical, social-economic and cultural barriers.

\section{METHODOLOGY}

Questionnaire was administered to rural farmers of the two sub-counties of Nabigwulu and Namwendwa in Bugabula County in Kamuli district. Interviews were conducted for the service providers.

\section{POPULATION}

The population of the study consisted of 62 respondents from the mentioned sub-counties above. 


\section{DATA ANALYSIS AND DISCUSSION}

The analysis of data presented was based on information provided by respondents of the two sub counties. A questionnaires was administered by the researchers to 95 respondents and only 62 questionnaires were received giving a response rate of $65 \%$. The analysis is therefore based on the 62 questionnaires received.

\section{ANALYSIS OF DEMOGRAPHIC DATA}

The distribution of the respondents by their personal data is shown in this section. Data were analyzed usingsimple percentage. The data in Table 1 is used to show the gender of respondents.

Table 1 - Distribution of the Respondents by Gender

\begin{tabular}{c|cc}
\hline Age (Years) & Frequency & Percent (\%) \\
\hline Female & 23 & 37 \\
Male & 39 & 63 \\
Total & $\mathbf{6 2}$ & $\mathbf{1 0 0}$ \\
\hline
\end{tabular}

From Table 1, it could be seen that majority $23(37 \%)$ of the respondents are males while females were $23(37 \%)$. The variation was attributed to the domestic commitments of the females while their counter parts remained home drinking and chatting with their male colleagues.

The data in Table 2 is used to show the ages of respondentes

Table 2 - Distribution of the Respondents by Age

\begin{tabular}{c|cccc}
\hline Age (Years) & Females & Males & Total Frequencies & Percent (\%) \\
\hline $\mathbf{2 1 - 3 0}$ & 3 & 9 & 12 & 19 \\
$31-40$ & 10 & 11 & 21 & 35 \\
$\mathbf{4 1 - 5 0}$ & 3 & 10 & 13 & 20 \\
$\mathbf{5 0}$ andabove & 7 & 9 & 16 & 26 \\
Total & $\mathbf{2 3}$ & $\mathbf{3 9}$ & $\mathbf{6 2}$ & $\mathbf{1 0 0}$ \\
\hline
\end{tabular}

Table 2 shows that majority of the respondents both females (10) and males (11) were in the age group 31-40. This is attributed to the fact that females are engaged in agricultural activity in the same age bracket with the males. 
Table 3 - Basic Activity of the Respondents

\begin{tabular}{c|cc}
\hline HighestLevelofEducation & Frequency & Percent (\%) \\
\hline Cropfarming & 32 & 32 \\
Mixedfarming & 19 & 30 \\
Livestockfarming & 8 & 3 \\
Poultry & 2 & 2 \\
Bee Keeping & 1 & 100 \\
Total & 62 & 3 \\
\hline
\end{tabular}

\section{AGRICULTURAL INFORMATION NEEDS OF RURAL FARMERS.}

A question was posed to find out the agricultural information needs of rural farmers. Below are some oftheir responses.

- Information on pests and disease control for both their animals and crops including what equipment should be used for this purpose.

- Information about where to market their products and also market prices

- Information on the best storage and preservation methods for their produce to avoid deterioration of their products quality.

- Information on how to improve the breed of their livestock and how to manage livestock production.

- Information on the different types of natural fertilizers that they can use for their crops to substitute the expensive artificial fertilizers available in the market.

- Information on varieties of the better quality seeds and where to acquire.

- Information on budgeting and record keeping in order keep track on the records of their sales and inputs.

- Information on what activities that farmers can carry out to generate income and at the same time information on how to start up projects like bee keeping.

\section{SOURCES OF INFORMATION}

Another question was asked "what are the sources of information?"Below are some of their responses.

- The respondents near extension workers go to them seeking for the required information.

- Others rely on the information they get at the seminars and meetings that they attend where they have discussions on farming. 
- Some of the farmers get their routine information from fellow farmers when they go for their routine work in their gardens.

- Others source of information is by radio where most of the respondents had access to radio and listen to their local language programme. The radio is widely used because it is relatively affordable and covers wider area.

- Non-Governmental Organization staff, the NGOs staff from Uganda Development Services and Kamuli District Farmers Association also play a fundamental role in disseminating information to the rural farmers. The NGO staff mainly organize seminars for the farmers where they give agricultural information to the farmers in respective of their interest groups, this is an effective methods because it gives the ICT providers to get feedback from the farmers.

Table 4 - ICT Equipment used by the respondentes

\begin{tabular}{c|cc}
\hline ICT Equipment & Frequencies & No. Of Respondents \\
\hline Radios & 54 & 88 \\
Mobile Phones & 5 & 9 \\
Television & 2 & 3 \\
Computers & - & - \\
Others & - & - \\
Total & 62 & 100 \\
\hline
\end{tabular}

As shown from Table 4, majority of the respondents own a radio (88\%) followed by Mobile phones (9\%) and Television Set (3\%) and none of the respondents had any other ICT equipment. The Radio was the mostly used to disseminate agricultural information to the rural farmers this is because it is affordable doesn't require power most of the times unlike other equipment, instead they can use the batteries.

\section{BENEFITS OF USING THE ICTS}

A question was asked regarding the benefits of using the ICTs by the respondents below are the responses.

- The rural farmers were able to acquire knowledge and use it to implement in their agricultural activities at home.

- Also with the knowledge acquired, the ICTs have reduced the distances of accessing agricultural information especially to farmers who stay very far. Therefore, it is faster and more efficient in delivery of information to the rural farmers.

- The radio for example provides a wider dissemination of information especially to the unreached or underserved in the rural areas. 
- ICTs have also helped to break the traditional barriers limiting access to information and knowledge by the rural farmers. This has been done with the use of the radio which reaches to wide range of farmers.

\section{CHALLENGES OF ACCESSING THE ICT FACILITIES}

\begin{tabular}{c|c} 
Challenge & No. Of Respondents \\
\hline Cells for the radio are very expensive & 20 \\
Lack of Knowledge about use of the other ICT facilities like computers & 10 \\
Lack of money to buy and acquire the ICT facilities & 34 \\
Inappropriate timing of the programmes on the radios or television sets & 19 \\
\hline
\end{tabular}

\section{STRATEGIES/ RECOMMENDATIONS}

The respondents were asked to provide strategies to improve access of the ICT facilities in rural areas below are the strategies proposed.

\begin{tabular}{c|c}
\hline Strategy & No. Of Respondents \\
\hline $\begin{array}{c}\text { Government should subside the costs of acquiring the ICT equipment } \\
\text { There is need for collaboration between the NGOs and communities } \\
\text { regarding agricultural information }\end{array}$ & 15 \\
$\begin{array}{c}\text { Need to train and educate the farmers about the ICTs and how they } \\
\text { can access agricultural information emphasis on basics not } \\
\text { complicated terms }\end{array}$ & 58 \\
$\begin{array}{c}\text { Train the extension workers who are nearer to the rural farmers on } \\
\text { the ICTs }\end{array}$ & 3 \\
$\begin{array}{c}\text { Radio batteries should be given to the rural farmers free by the } \\
\text { government or reduce on taxes and costs }\end{array}$ & 51 \\
$\begin{array}{c}\text { Government should establish ICT Training Centers for the rural } \\
\text { farmers }\end{array}$ & 10 \\
\begin{tabular}{c} 
Timing of the Agricultural programmes should be aired at night \\
\hline
\end{tabular} & 18 \\
\hline
\end{tabular}

From the above responses the agricultural farmers raised pertinent proposals that need to be address for the country to improve on its agricultural sector. Majority of the farmers (58) proposed the need for training and education about the ICTs and also how they can access the agricultural information using the ICTs. This is in relationship with the 15 responses that government should establish ICT Training Centers which should be nearer to them so that they don't have to walk long distances to access the trainings. Furthermore, the cost of the Radio batteries was also proposed since majority of the rural farmers have access to the radio, they proposed to reduce the costs of the batteries or even receive them free from the government.

\section{SUMMARY AND CONCLUSION}

Basing on the findings, the radio was identified as the most popular channel of disseminating agricultural information by the rural farmers because most of 
the households own them. It should however, be noted that ICTs have not yet been made available to the rural farmers because of the costs involved in accessing the equipment; similarly the farmers have not formal training on the various ICT tools which could help with easy and access of this information. Therefore, there is need for the government to prioritize the use of ICTs in the agriculture sector to improve on productivity which will improve the economy; the government should subside the costs of acquiring these ICT facilities especially for the rural farmers would can't afford them; the rural communities should also be introduced to the various ICTs; timing of the radio programmes should be aired in the evenings when they farmers are not in the farms. 


\section{Fazendo ITCs relevantes para os agricultores rurais de Uganda: 0 caso do distrito de Kamuli}

\section{RESUMO}

ITCs representam Informações e Tecnologias de Comunicação, tem sido amplamente definida pela Comissão de Comunicação Uganda como tecnologias que proporcionam um ambiente favorável à infraestrutura e serviços de desenvolvimento físico de aplicação para a geração, o processamento de transmissão, armazenamento e divulgação de informações em todas as formas, incluindo voz, textos, dados, gráficos e vídeo. TIC não são efetivamente comunicadas aos agricultores, especialmente em áreas rurais, embora o acesso à tecnologia de informação moderna é largamente disponível. Este trabalho irá analisar a relevância das TIC para os agricultores rurais em Uganda. Os objetivos do estudo são investigar as necessidades de informação agrícola dos agricultores rurais no distrito de Kamuli; para identificar as instalações de TIC utilizados para a disseminação de informação agrícola para agricultores rurais. O tamanho da amostra foi de 62 respondentes. A amostragem aleatória foi utilizada na identificação dos respondentes. Questionários foram utilizados para solicitar respostas dos entrevistados. Os dados foram analisados usando o Excel e apresentados em tabelas. A partir do estudo, a maioria dos inquiridos eram do sexo masculino e o rádio era o equipamento principalde TIC utilizado para aceder a informação agrícola. Um dos principais desafios para o acesso do TIC é financiamento e formação inadequada. Portanto, recomenda-se a necessidade de intervenção do governo para fornecer subsídios e também estabelecer setores de formação para os agricultores rurais para acessar a informação agrícola em outras instalações de TIC.

PALAVRAS-CHAVE: ITC. Os agricultores rurais. Divulgação. 


\section{REFERENCES}

BARYAMUREEBA, V.ICT as an Engine for Uganda's Economic Growth: The Role of and Opportunities. Growth (Lakeland), 468-483.2004.

CESPEDES, L. M. (2013). How ICT tools are improving efficiency of agricultural development. From:<http://www.theguardian.com/global-developmentprofessionals-network/2013/ian/24/data-collection-evaluation-technologyagriculture>. Retrieved May 14, 2016.

CTA. Assessment of agricultural information needs in African, Caribbean \& Pacific (ACP) states. Exchange Organizational Behavior Teaching Journal, (November). 2005.

DAS, S. K. ICT in Agriculture.From:

<https://shivkumardas.wordpress.com/2013/08/08/ict-in-agriculture-3/FAO>. ICT Uses for Inclusive Agricultural Value Chains. Rome. 2013. Retrieved May 19, 2016.

GOLLIN, D.;ROGERSON, R. (2010). Agriculture, Roads and Economic Development inUganda. From: <http://doi.org/10.1029/2006WR005130.CCME>.

HALL, T.ICT: Changing the Face of Agriculture. from:

<http://www.ictworks.org/2011/10/12/ict-changing-face-agriculture/>. Retrieved May 19, 2016.

ISAYA, E. L.Sources of Agricultural Information for Women Farmers in Hai andKilosa Districts, Tanzania. Ohio State University.2015. Retrieved from: $<$ https://etd.ohiolink.edu/!etd.send file?accession=osu1420647091\&disposition =inline $>$.

JONES, D. E.Sources of Agricultural Information. Library Trends, 38(3), 498-516. 1990.

KOBUSINGE, G.An ICT Framework to Enhance Food Security in Rural Communities of Uganda. Makerere University. 2009.

MUSA, N.Challenges of using information and communication technologies to disseminate agricultural information to farmers in Sudan, 3(2), 1-17.2013.

OBIDIKE, N. A. Rural farmers' problems accessing agricultural information: a case study of Nsukka local government area of Enugu State, Nigeria. Library Philosophy andPractice. 2011. 
OZOWA, V. N.Information Needs of Small Scale Farmers in Africa: The Nigerian Example. Quarterly Bulletin of the International Association of Agricultural Information Specialists, IAALD/CABI, 40(1). 1995. Retrieved from: <http://www.worldbank.org/html/cgiar/newsletter/june97/9nigeria.html>.

QIANG, C. Z.;KUEK, S. C.;DYMOND, A.;ESSELAAR, S.Mobile Applications for Agriculture and Rural Development, (May), 120. 2012. Retrieved from: $<$ http://siteresources.worldbank.org/INFORMATIONANDCOMMUNICATIONANDT ECHNOLOGIES/Resources/MobileApplications for ARD.pdf>.

RAMLI, N. S.;HASSAN, M. S.; SAMAH, B. A.;ALI, M. S. S.;SHAFFRIL, H. A. M.;AZAHARIAN, Z. S. (2013). Problems in using agricultural information from television among farmers inMalaysia.Asian Social Science, 9(9), 70-73. 2013. From: <http://doi.org/10.5539/ass.v9n9p70>.

RAO, M. S.;PADMAJA, K.;KUMAR, G. K.;PRASAD, D. J.Relevance of Content in ICT Initiatives in Agriculture- SasyaSree - a one stop shop Telugu portal. In ICT use in agriculture. Hyderabad. 2015.

THE INTERNATIONAL BANK FOR RECONSTRUCTION AND DEVELOPMENT, \& The World Bank. (2011).ICT In Agriculture: Connecting Smallholders to Knowledge , Networks, and Institutions. eSOURCEBOOK. Washington, D.C. 2011.Retrieved from: $<$ http://www.ictinagriculture.org/>.

TURYAREEBA, P. J.Renewable energy: Its contribution to improved standards of livingand modernisation of agriculture in Uganda. Renewable Energy, 24(3-4), 453-457. 2001. From: <http://doi.org/10.1016/S0960-1481(01)00028-3>.

ZYL, O. Van; ALEXANDER, T.; GRAAF, L. De;MUKHERJEE, K.; KUMAR, V. (2014). ICTs for agriculture in Africa, 1-32. Retrieved from:<http://documents.worldbank.org/curated/en/2014/01/19554707/ictsagriculture-africa $>$. 
Recebido: 08 abr. 2016

Aprovado: 03 jun. 2016.

DOI: $10.3895 /$ rbpd.v5n2.4498

Como citar: AKULLO, W. N.; MULUMBA, O. Making ICTs relevant to rural farmers in Uganda: A Case of Kamuli District. R. bras. Planej. Desenv.,Curitiba, v. 5, n. 2, p. 291-304, mai./ago. 2016. Disponível em: $<$ https://periodicos.utfpr.edu.br/rbpd>. Acesso em: XXX.

\section{Correspondência:}

Winny Nekesa Akullo

Nakasero Towers, Plot 39/P.O.Box 3925,Kampala Uganda Nakasero Rd, Kampala, Uganda

Direito autoral: Este artigo está licenciado sob os termos da Licença CreativeCommons-Atribuição 4.0

Internacional.

(c) (1) 